\title{
A Case of a Synchronous Peripheral T-cell Lymphoma in a Patient with Systemic Lupus Erythematosus
}

\author{
Hea Jung Sung, M.D., Kwang II Seo, M.D., Ji Hyung Hong, M.D., \\ Sang Young Roh, M.D., Young Seon Hong, M.D. and Yoon Ho Ko, M.D. \\ Division of Oncology, Department of Internal Medicine, The Catholic University of Korea, Seoul, Korea
}

\begin{abstract}
Systemic lupus erythematosus (SLE) patients tends to have a higher risk of developing lymphoid malignancies. The majority of such tumors are of a B cell origin. However, it is known that the T cell lymphoma subtypes in SLE patients are quite rare. Here, we describe a case of peripheral T cell lymphoma, unspecified (PTCL-U) that occurred in a 50-year-old female SLE patient. The lymphoma was located at the bilateral cervical and mediastinal lymph nodes. The staging workup revealed no evidence of any other organ involvement. Epstein-Barr virus messenger RNA was detected in the serum, but not in the lymph nodes. She received front-line chemotherapy with the CHOP regimen and she achieved complete remission. She then subsequently received high-dose chemotherapy with autologous peripheral stem cell transplantation. The patient currently remains in a clinical and serological state of remission for the SLE and PTCL until the time of this report 18 months after chemotherapy, and this was followed by autologous peripheral blood stem cell transplantation. (Korean J Hematol 2009;44:273-277.)
\end{abstract}

Key Words: Lymphoma, T cell, Peripheral, Lupus erythematosus, Systemic, Peripheral blood stem cell transplantation

\section{INTRODUCTION}

A recent International Lymphoma Study Group study of 1,378 cases of non-Hodgkin's lymphoma (NHL) has found that $7 \%$ of the cases represented peripheral T-cell lymphoma (PTCL). ${ }^{1)}$ PTCL is not geographically distributed evenly throughout the world. The condition develops more frequently in Asia than in Western countries. ${ }^{2)}$ There are many causes of the development of NHL and infection with viruses, such as Epstein-Barr virus (EBV) is one of them. ${ }^{3,4)}$ Systemic lupus erythematosus (SLE) also results in a higher risk for the development of all cancer types. Hodgkin's lymphoma, Burkitt's lymphoma, low-grade lymphoma, and diffuse

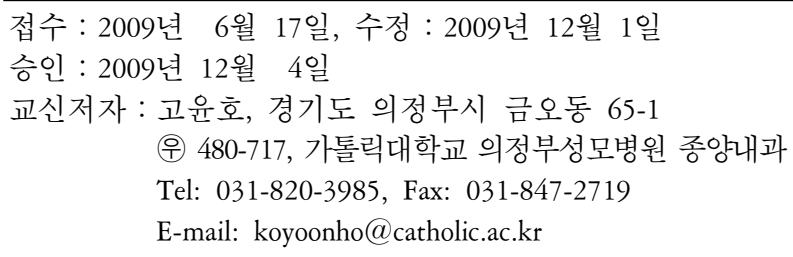

large B-cell lymphoma have been reported as SLE-associated neoplasms. ${ }^{5)}$ However, it is known that T-cell lymphoma subtypes are rare in SLE patients. Here, we present a case of PTCL that occurred two months after the onset of SLE.

\section{CASE REPORT}

A 50-year-old woman was referred to the Department of Medical Oncology from the Department of Rheumatology due to a palpable neck mass that had increased in size over one week. The patient had suffered from polyarthralgia over three years, and presented two months prior, complaining of high-grade fever, arthralgia, and skin rash. At that time, the patient was diag-

\footnotetext{
Correspondence to : Yoon Ho Ko, M.D.

Division of Oncology, Department of Internal Medicine, Uijeongbu

St. Mary's Hospital, The Catholic University of Korea

65-1, Geumo-dong, Uijeongbu 480-717, Korea

Tel: +82-31-820-3985, Fax: +82-31-847-2719

E-mail: koyoonho@catholic.ac.kr
} 
nosed with SLE, based on the findings of elevated ESR (36 mm/h), reduced C3 $(64.2 \mathrm{mg} / \mathrm{dL}$ [normal, 90 $180]) / \mathrm{C} 4(12.6 \mathrm{mg} / \mathrm{dL}$ [normal, 10 40]), a strong positive titer $(1: 1600)$ for serum antinuclear antibodies (ANA), and a positive anti-dsDNA assay (715.5 IU/ $\mathrm{mL}$ ), for which she received $30 \mathrm{mg}$ per day of prednisone, and her symptoms improved for a while.

Her ECOG performance status score was 1. Physical examination conducted on admission showed that multiple small, but enlarged, lymph nodes were palpable on the bilateral cervical area; they were firm, fixed, and non-tender. A complete blood count revealed as follows: hemoglobin $13.9 \mathrm{~g} / \mathrm{dL}$, hematocrit $43.2 \%$, white blood cells $6.26 \times 10^{9} / \mathrm{L}$, neutrophils $5.38 \times 10^{9} / \mathrm{L}$, lymphocytes $0.69 \times 10^{9} / \mathrm{L}$, monocytes $0.15 \times 10^{9} / \mathrm{L}$, and platelets $202.0 \times 10^{9} / \mathrm{L}$. The ESR was $47 \mathrm{~mm} / \mathrm{h}$. Blood chemistry including liver and renal function tests showed no significant abnormality. Complement C3 $(50.3 \mathrm{mg} / \mathrm{dL}$ [normal, 90 180]), C4 (10.7 mg/dL [normal, 10 40]), and elevated serum LDH (556 U/L [normal, <400 $\mathrm{U} / \mathrm{L}])$. The patient evidenced a diffuse hypergammaglobulinemia, with $\operatorname{IgG} 1,620 \mathrm{mg} / \mathrm{dL}, \operatorname{IgA} 477 \mathrm{mg} / \mathrm{dL}$, and IgM $391 \mathrm{mg} / \mathrm{dL}$. Serum ANA was positive, with a titer of $1: 1600$, and the homogenous pattern of fluorescence and anti-dsDNA was strongly positive (400 $\mathrm{IU} / \mathrm{mL}$ ). Antibodies to other soluble extracted nuclear antigens (ENA) were positive. The level of lupus anti-

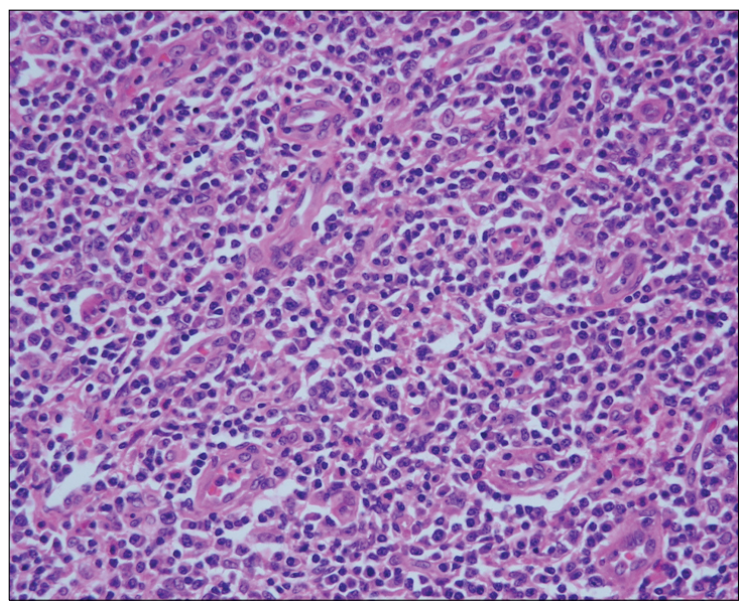

Fig. 1. Lymphoma cells are small-to-medium in size and have oval-shaped nuclei with irregular contours, coarse chromatin, and moderate amounts of pale cytoplasm (H\&E, $\times 400)$. coagulant antibody, 1.2, was within the normal range (0.8 1.2). EBV capsid antigen (VCA) antibody detection was negative for IgM, but remained positive for the IgG antibody (2.25 index, [normal, <0.9]). IgM antibody to EBV early antigen (EA) was positive (83 $\mathrm{U} / \mathrm{mL}$ [normal, $<8 \mathrm{U} / \mathrm{mL}$ ]), whereas the IgG antibody was negative. Additionally, the patient's whole-blood samples were positive for EBV by polymerase chain reaction. However, nuclear signals for EBV mRNA by EBER1 in situ hybridization were not detected in tumor tissues. Other serological tests, including those for hepatitis $\mathrm{B}$ and $\mathrm{C}$ virus, herpes simplex virus, and HIV, were all negative.

Bone marrow aspirates and biopsy specimens revealed no significant abnormality. A computed tomography scan revealed the presence of multiple enlarged lymph nodes within the cervical and mediastinal area. The diagnosis of peripheral $\mathrm{T}$ cell lymphoma, unspecified (PTCL-U), an age-adjusted International Prognostic Index (a-IPI) of 1, was established via the histological examination of an enlarged cervical lymph node. A low-power examination of the biopsied lymph node revealed diffuse effacement of nodal architecture by neoplastic lymphocytes. The lymph nodes were prominent, with numerous hyperplastic vessels of the post-capillary venule type, coupled with an admixture of atypical lymphoid cells and plasma cells (Fig. 1). Immunohistochemically, the tumor cells tested positive for $\mathrm{CD} 3$, but negative for CD15, CD20, CD30, and CD56 (Fig. 2). A

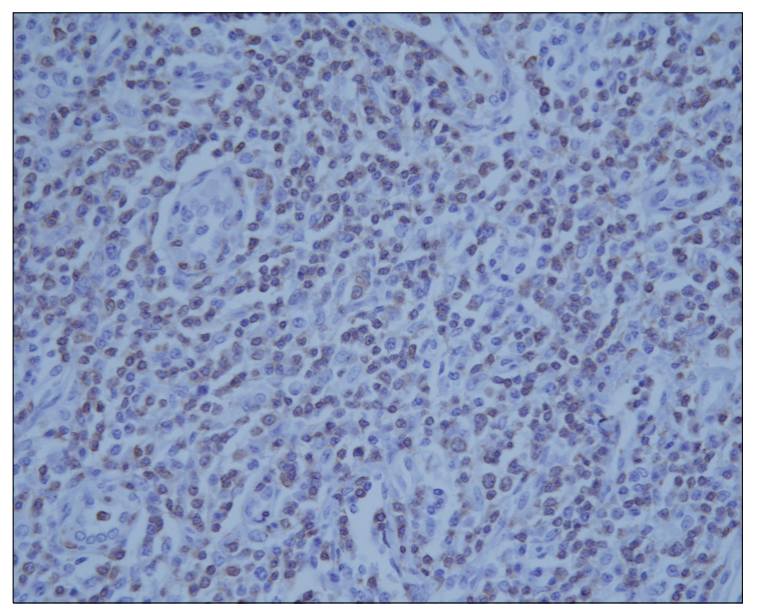

Fig. 2. Immunohistochemistry, showing the cells to be strongly positive for the T-cell marker CD3 $(\times 400)$. 
molecular genetic study of the lymph nodes demonstrated the presence of a gamma T-cell receptor gene rearrangement.

Six cycles of chemotherapy with CHOP (cyclophosphamide, doxorubicin, vincristine, and prednisone) regimen were administered. Complete remission of both PTCL and SLE was observed following six courses of chemotherapy. As shown in Table 1, the serum complement factors and antibodies to dsDNA were normalized. Nonetheless, the serum ANA was still positive, at a titer $1: 100$ homogenous pattern of fluorescence. As PTCL is an unfavorable histological type of NHL, the patient subsequently received autologous peripheral blood stem cell transplantation (PBSCT). Peripheral blood stem cell transplantation (PBSCT) were harvested via large volume leukapheresis for three consecutive days. Recombinant human granulocyte-colony stimulating factor $5 \mu$ $\mathrm{g} / \mathrm{kg}$ was administered to facilitate stem cell mobilization following the administration of IVAM (ifosfamide, etoposide, cytarabine, and methotrexed) regimen therapy. The harvested PBSCs were $7.19 \times 10^{8}$ mononuclear cells $/ \mathrm{kg}$ and $41.94 \times 10^{6} \mathrm{CD} 34+$ cells $/ \mathrm{kg}$. A high-dose ICE (ifosfamide $12 \mathrm{~g} / \mathrm{m}^{2}$, carboplatin $1,800 \mathrm{mg} / \mathrm{m}^{2}$, and etoposide $1,200 \mathrm{mg} / \mathrm{m}^{2}$ ) chemotherapy was used as a conditioning regimen. The patient evidenced good recovery after autologous PBSCT, and remains in clinical and serological remission of SLE and PTCL-U at the time of this report, 18 months after chemotherapy.

\section{DISCUSSION}

Patients with autoimmune diseases, such as rheumatoid arthritis, SLE, Sjögren's syndrome, psoriasis, and celiac disease, are more susceptible to the development of lymphomas. ${ }^{6}$ ) A recent, large pooled analysis demonstrated that SLE was associated with a 2.7-fold increased risk of NHL. In contrast, the T-cell NHL risk was greater for patients with celiac disease and psoriasis. ${ }^{7)}$ Mature B cell lymphomas are the predominant pathologic subtype in SLE patients, and diffuse large B cell lymphoma has been identified as the most frequent subtype.,7) However, it has been demonstrated that T-cell lymphomas are quite rare in SLE patients. Moreover, the synchronous or metasynchronous occurrence of SLE with
T-cell malignancy is rarely reported.

The reasons for the increased risk of NHL in patients with SLE remain largely unknown. Immune dysregulation, immunosuppressive drugs, and EBV infection may act as common etiologic factors in both disorders. $\left.{ }^{9}, 10\right)$ Genetic abnormalities, including dysfunction in apoptosis and lymphocyte proliferation, may represent a common pathway that links SLE and lymphoproliferative malignancies. ${ }^{5)}$ Additionally, it would appear that the long-term use of immunosuppressive drugs increases the risk of NHL. However, B-cell lymphomas that develop without exposure to immunosuppressive therapy have been reported. ${ }^{8)}$ Accordingly, the temporary (two month) use of prednisone in this case seems unlikely to explain the development of NHL.

Despite many studies of the pathogenesis of SLE, causal relationships between viruses and the presentation/exacerbation of autoimmune diseases remain ill-defined. However, EBV, the etiologic agent of infectious mononucleosis, is thought to contribute to the pathogenesis of both SLE and NHL. Recent EBV infection or viral reactivation often occurs in SLE patients. ${ }^{11)}$ EBV has also been detected in a number of lymphoid malignancies, including Burkitt's lymphoma, immunodeficiency-associated lymphoproliferative disorders, extranodal NK/T-cell lymphoma, and Hodgkin's disease. ${ }^{4)}$ Additionally, it has been shown that EBV can contribute to the development of PTCL. ${ }^{3)}$ T-cell neoplasms in Eastern Asia are significantly associated with $\mathrm{EBV}$, and it appears that EBV performs an important function in tumorigenesis, which was confirmed by a clonality study. ${ }^{12)}$ In this case, although we did not assess the levels of IgA antibodies, serological data demonstrated a recent infective process, rather than reactivation of EBV. However, we did not detect EBV in tumor tissue. Thus, we were unable to clarify whether EBV played a role in the development of PTCL-U in this SLE patient.

PTCL-U represents the largest PTCL subtype. In the WHO classification PTCL-U encompasses all of the PTCLs not classifiable as a specific disease entity in contrast to the rare, but "specified," subtypes. It is clear that this represents a heterogeneous group of diseases and although multiple morphologic subtypes have been reco- 
gnized. The majority of nodal cases are $\mathrm{CD} 4+$ and $\mathrm{CD} 8$, and CD30 can be expressed in large cell variants. ${ }^{13)}$ In the case of our patient, anaplastic large-cell lymphoma was excluded by the lack of CD30 expression. T/NKcell lymphoma was unlikely because tumor cells did not express CD56. In the case of our patient, histologic and immunophenotypic features were consistent with PTCLU.

In this case, the complete remission of NHL and SLE was achieved via treatment with cytotoxic agents. There is little reported information regarding cancer treatment given to SLE patients who developed NHL, or data regarding their response and relapse rates following treatment. ${ }^{8)}$ Considering the high incidence of aggressive lymphoma in SLE patients, this indicates that SLE patients who develop NHL do not get along as well as most patients with NHL. Additionally, with regard to the clinical outcome, a T-cell immunophenotype (with the exception of anaplastic large cell lymphoma) is an independent predictor of poor prognosis in aggressive lymphomas. ${ }^{14)}$ Furthermore, a recent Groupe d'Etude des Lymphomes de l'Adulte (GELA) study indicated that EBV was a prognostic factor for the detection of $\mathrm{EBV}$, which was associated with the worst outcomes in a PTCL population of various histological subtypes. ${ }^{13)}$ Taking together, this case was considered to have a high risk of relapse. High-dose chemotherapy and autologous PBSCT has been accepted as effective relapsed or high-risk NHL in complete remission. It has also been reported that the prolonged remission of SLE was achieved after PBSCT for NHL. ${ }^{15)}$ Given all of these facts, high-dose chemotherapy with stem cell rescue was indispensable to the successful treatment in this case. The $\mathrm{pa}^{-}$ tient in this case had clinical and serological remission of SLE and PTCL-U. The potential effects of PBSCT on the course of SLE and lymphoproliferative disorders have been considered.

\section{요 약}

전신성 홍반성 루푸스(SLE)는 악성 림프종 발생 위 험도가 높은 질환이다. SLE 환자에서 발생하는 림프종 은 대부분 $\mathrm{B}$ 세포 기원의 림프종이며 $\mathrm{T}$ 세포 림프종은 드물다. 저자들은 양쪽 경부림프절 종대로 내원한 50
세 SLE 여자환자에서 말초 T세포 림프종 (PTCL-U)을 진단하고 치료한 사례를 경험하고 이를 보고하고자 한 다. 면역조직화학검사에서 림프종 세포들은 $\mathrm{CD} 3$ 을 발 현하였으나 $\mathrm{CD} 15, \mathrm{CD} 20, \mathrm{CD} 30$ 및 $\mathrm{CD} 56$ 은 음성이었 고 조직학적으로 PTCL-U에 합당하였다. 병발된 림프 절에서 Epstein-Barr virus messenger RNA는 검출 할 수 없었으나 혈청검사에서 관찰되었다. 환자는 21 일 주기의 표준항암요법(CHOP)을 6회 투여 후 완전관해 에 도달하였고, 재발위험도를 줄이기 위해 고용량 항 암화학요법(ICE) 및 자가 말초혈액 조혈모 세포이식 술을 시행받고, 현재 18 개월째 완전관해 상태로 외래 추적 중이다.

\section{REFERENCES}

1) A clinical evaluation of the International Lymphoma Study Group classification of non-Hodgkin's lymphoma. The Non-Hodgkin's Lymphoma Classification Project. Blood 1997;89:3909-18.

2) Anderson JR, Armitage JO, Weisenburger DD. Epidemiology of the non-Hodgkin's lymphomas: distributions of the major subtypes differ by geographic locations. Non-Hodgkin's Lymphoma Classification Project. Ann Oncol 1998;97:717-20.

3) Jones JF, Shurin S, Abramowsky C, et al. T-cell lymphomas containing Epstein-Barr viral DNA in patients with chronic Epstein-Barr virus infections. N Engl J Med 1988;318:733-41.

4) Chang KL, Weiss LM. The association of the Epstein-Barr virus with malignant lymphoma. Biomed Pharmacother 1996;50:459-67.

5) King JK, Costenbader KH. Characteristics of patients with systemic lupus erythematosus (SLE) and non-Hodgkin's lymphoma (NHL). Clin Rheumatol 2007;26:1491-4.

6) Grulich AE, Vajdic CM. The epidemiology of nonHodgkin lymphoma. Pathology 2005;37:409-19.

7) Ekström Smedby K, Vajdic CM, Faslster M, et al. Autoimmune disorders and risk of non-Hodgkin lymphoma subtypes: a pooled analysis within the InterLymph Consortium. Blood 2008;111:4029-38.

8) Suvajdzic N, Stojanovic-Milenkovic R, Tomasevic Z, Cemerikic-Martinovic V, Mihaljevic B, Atkinson HD. ALK-negative T-cell anaplastic large cell lymphoma associated with systemic lupus erythematosus. Med Oncol 2003;20:409-12.

9) Graninger WB, Smolen JS. Should the clinician have interest in the deregulation of apoptosis in auto- 
immunity? Br J Rheumatol 1997;36:1244-6.

10) $\mathrm{Xu} \mathrm{Y,} \mathrm{Wiernik} \mathrm{PH.} \mathrm{Systemic} \mathrm{lupus} \mathrm{erythematosus}$ and B-cell hematologic neoplasm. Lupus 2001;10: 841-50.

11) Huggins ML, Todd I, Powell RJ. Reactivation of Epstein-Barr virus in patients with systemic lupus erythematosus. Rheumatol Int 2005;25:183-7.

12) Huh J, Cho K, Heo DS, Kim JE, Kim CW. Detection of Epstein-Barr virus in Korean peripheral T-cell lymphoma. Am J Hematol 1999;60:205-14.

13) Dupuis J, Emile JF, Mounier N, et al. Prognostic significance of Epstein-Barr virus in nodal peripheral
T-cell lymphoma, unspecified: a Groupe d'Etude des Lymphomes de l'Adulte (GELA) study. Blood 2006; 108:4163-9.

14) Ansell SM, Kurtin PJ, Stenson M, et al. Evaluation of the proliferative index as a prognostic factor in diffuse large cell lymphoma: correlation with the International Index. Leuk Lymphoma 1999;34:529-37.

15) Snowden JA, Patton WN, O'Donnell JL, Hannah EE, Hart DN. Prolonged remission of longstanding systemic lupus erythematosus after autologous bone marrow transplant for non-Hodgkin's lymphoma. Bone Marrow Transplant 1997;19:1247-50. 